\title{
DO DIEL VARIATIONS IN STREAM FISH ASSEMBLAGES DEPEND ON SPATIAL POSITIONING OF THE SAMPLING SITES AND SEASONS?
}

\author{
István Czeglédi ${ }^{1,2 *}$, Péter Sály ${ }^{2}$, Péter Takács² ${ }^{2}$ Anna Dolezsai ${ }^{2}$ \\ Zoltán Vitál ${ }^{2}$, Alex SÁndor Nagy ${ }^{1}$ and Tibor Erős ${ }^{2}$ \\ ${ }^{1}$ University of Debrecen, Department of Hydrobiology \\ H-4032 Debrecen, Egyetem tér 1, Hungary \\ ${ }^{2}$ Balaton Limnological Institute, MTA Centre for Ecological Research \\ Klebelsberg K. u. 3., H-8237 Tihany, Hungary \\ *Corresponding author: mullercega@gmail.com
}

The effect of diel period (i.e. day vs night) and its dependence on the spatial position of the sampling site were evaluated on the assessment of fish assemblage attributes in a wadeable lowland stream (Hajagos stream, Hungary). Species richness, composition and abundance data of two $150 \mathrm{~m}$ long reaches, one situated directly at the tributary mouth and one $6 \mathrm{~km}$ upstream were compared using three pass removal by electrofishing in three seasons (summer, autumn and spring) to test the effect of spatial position on day and night patterns. No differences in any assemblage level variables were found between day and night. Although fish assemblages showed large temporal variations, spatial position of the sampling site had the most influential effect on fish assemblage attributes compared with seasonal and/ or day night patterns. Consequently, the diel period had rather negligible effect in the studied stream. Daytime electrofishing data seems to be highly representative for the accurate assessment of fish assemblages in relatively small (less than $5 \mathrm{~m}$ wide) wadeable streams and maybe used reliably for any model of community organization (e.g. food web studies).

Key words: day vs night, sampling, electrofishing, spatial position, tributary mouth.

\section{INTRODUCTION}

The accurate estimation of assemblage level attributes (e.g. species richness, species composition and abundance) is a fundamental requirement in ecological research and environmental monitoring and assessment (MAHER et al. 1993, Cao et al. 2003, Meador et al. 2003, Kennard et al. 2006). However, most of our knowledge about the structure and organization of ecological assemblages is based on daytime samples. It has been shown, that the activity of animals can be different between day and night, which may influence sampling effectiveness (Craig 1977, Pierce et al. 2001, Anderson et al. 2007). Movement of animals among different habitat patches can also differ between day and night (Nielsen 1984, Helfman 1993, David \& Closs 2003, Railsback et al. 2005). Therefore, samples collected either at day or night may reveal different pictures of assemblage structure, which can substantially influence our inferences on patterns and processes in ecosystems. 
Structure of fish assemblages have been long recognized to show contrasting day and night pattern. In freshwater systems for example, diel changes have been found to be significant in the littoral zone of lakes and reservoirs (Baumann \& Kitchell 1974, Lewin et al. 2004, Riha et al. 2015) and rivers (Sanders 1992, Copp \& Jurajda 1993, Arrington \& Winemiller 2003, Erős et al. 2008). Several studies showed that night time samplings yielded more species and specimens and greater biomass than day time samplings in the nearshore habitats of rivers because of higher catching efficiency, diel migration of many species to the littoral zone and higher movement activity by night (Copp \& Jurajda 1993, Wolter \& Freyhof 2004, Erős et al. 2008). It was concluded that both diurnal and nocturnal samplings are required to adequately characterize fish assemblages, especially in large rivers, which are difficult to sample representatively (Wolter \& Freyhof 2004, Copp et al. 2005, Baumgartner et al. 2008).

Interestingly, much less research has been devoted to diel changes and their effect on estimating fish assemblage variables in smaller (i.e. wadeable) streams (but see e.g. Copp 2010, SAlas \& SNYDER 2010). This is probably because these habitats are considered to be more easily and representatively sampled using e.g. electrofishing or seine netting (see MurPHY \& Willis 1996, Matthews 1998) compared with large rivers (Grossman \& RatajczaK 1998, LAPOINTE et al. 2006). In fact, diel differences in the habitat use and activity of certain fishes are relatively well known (Reebs 2002, Salas \& SNYder 2010). For example, salmonids have been shown to use different habitats for feeding and hiding and habitat selection can differ between seasons and diel periods (e.g. Cunjak et al. 1998, Hiscock et al. 2002). However, it is much less known how differences in the habitat use and/or sampling effectiveness of individual species scale up to the assemblage level causing differences in the estimation of assemblage level attributes between day and night samples.

Day and night differences in fish assemblage samples may also depend on the spatial position of the sampling site. Daytime samplings showed that tributary mouths are more intensively used by mainstream fishes as refugee and feeding areas than more upstream reaches (Osborne \& Wiley 1992, Schlosser \& Angermeier 1995, Thornbrugh \& Gido 2010). Therefore, assemblages close to the mouth may be more variable than more upstream sites (ERős \& Schmera 2010, RoberTs \& Hitt 2010). Since fish migration patterns can be more intense downstream and may show a diel pattern, it can be hypothesized that differences between day and night samples will be the most contrasting close to the tributary mouth and may mitigate upstream as the number of migrants from the species pool outside the focal stream diminish. However, to our knowledge, no study to date has quantified day and night differences and the effect of the spatial positioning of the sampling site on estimating assemblage level variables for stream fishes. 
Seasonal changes (e. g. floods vs. droughts, differences in stream temperature) are one of the most important factors influencing assemblage organization and movement patterns of fish (Schlosser 1991). For example, movement activity of fish increases in spring due to spawning. Diel changes in activity and habitat use of fish may also be affected by seasonality (CRAIG 1977, CUNJAK et al. 1988, HegGenes et al. 1993). Although diel variation in movement patterns may be as important as seasonal differences at the species level, seasonal changes are presumably more significant at the assemblage level, especially in small streams. For these reasons we hypothesized that seasonal differences in fish assemblages will be more significant than diel changes, and diel patterns of fish movement will be determined by seasons.

The aim of this study was to test the effect of seasonal differences, site spatial positioning and diel differences on fish in a tributary system in term of species richness, composition and abundance of fishes standardized for unit area.

\section{MATERIAL AND METHODS}

\section{Study area and field sampling}

The study was conducted in the Hajagos stream, a right side tributary of the $100.4 \mathrm{~km}$ long lowland Marcal River, situated in North-Western Hungary (Fig. 1). The Hajagos has a length of $33.3 \mathrm{~km}$, an avarage slope of $4.3 \mathrm{~m} \mathrm{~km}^{-1}$ and a total drainage area of $188 \mathrm{~km}^{2}$. The riverbed is covered by diverse substrate dominating by coarse-gravel, fine-gravel, sandysilt and organic debris. The middle and downstream parts of the stream run through a predominantly agricultural landscape. Like the majority of lowland streams in Hungary, the Hajagos was channelized, which does not allow meandering. The macrophytes were dominated by emergent plants, such as reed (Phragmites australis), bulrush (Typha spp.) and sedge (Carex spp.), which can dramatically increase their biomass in the vegetation period covering even $100 \%$ of the riverbed.

For the purpose of this study we chose two sampling reaches, Site 1, the downstream sampling point situated directly at the tributary mouth, and Site 2 approximately $6 \mathrm{~km}$ upstream from the tributary mouth (Fig. 1). Electric fishing was carried out during both daytime and nightime in three sampling periods: summer (July) and autumn (October) 2013 and spring (April) 2014 using a back-pack electrofishing machine (Hans-Grassl IG200/2B, PDC, 75-100 Hz, 350-650 V, max. 10 kW; Hans Grassl GmbH, Germany). The stream was not sampled in winter due to the difficulties of sampling and installation of the nets in icy water. In addition, a winter sampling can disturb the resting fish and may cause high-level mortality. Each sampled reach was $150 \mathrm{~m}$ long and was further divided into $50 \mathrm{~m}$ long sampling units. Prior to electrofishing we blocked each unit at both ends with weighted nets ( $6 \mathrm{~mm}$ mesh size) to prevent fish movement in and out of the units. The nets were manipulated in the same way both during day and night samplings. Lower parts of the nets were strengthened with chains and they were fixed at the banks with steel rods. We always started sampling the most downstream unit at each site and then continued with the more upstream units. The sampling team consisted of four people: the electrofisher operator who handled the gear and caught the stunned fish with the hand-held anode (2 
$\mathrm{m}$ long pole with a net of $30 \mathrm{~cm}$ diameter, mesh size $6 \mathrm{~mm}$ ), a netter who helped to catch fish and two helpers who carried the buckets and took care of the fish. To increase the sampling efficiency each unit was electrofished three-times in the same manner. We sampled the whole stream width (moved in a zig-zag fashion) while slowly wading in an upstream direction. During each pass the fish were removed from the stream and placed immediately into a large, plastic tank filled with water. We identified the fish to species level on each pass, counted and measured their standard length and finally returned to the stream downstream of the studied sampling unit. Minimum 15 minutes were allowed to elapse between the individual passes. Data of successive removals (i.e. of individual passes) were pooled and this was used in all statistical evaluations. A minimum of six hours elapsed between day and night collections. During darkness, the sampling area was illuminated using head lamps.

We also took transect based measurements of habitat data at each unit to characterize the environmental features of the sampling sites in each season (Table 1). For this purpose

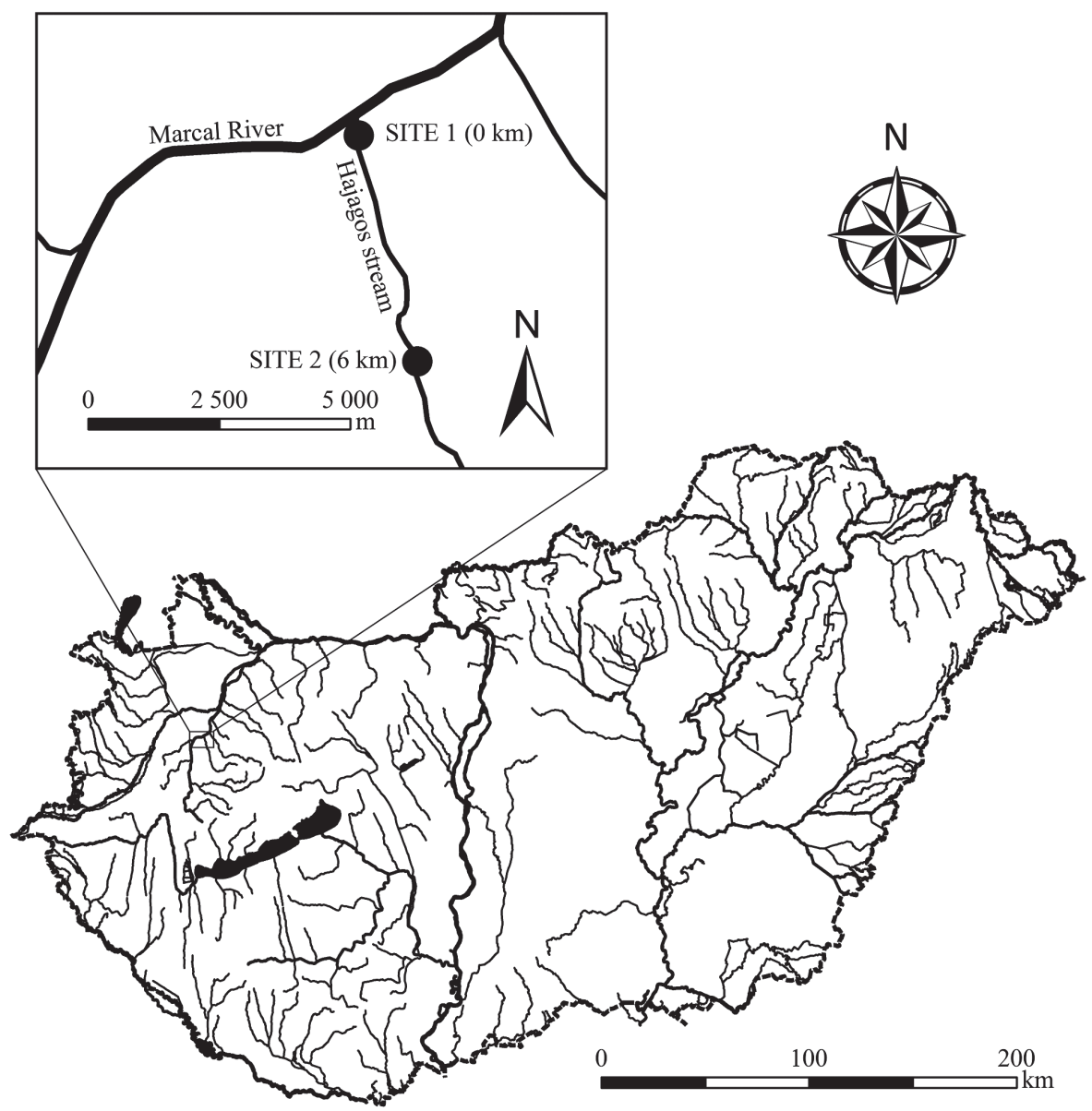

Fig. 1. Map showing the locations of sampling sites in Hajagos stream, Hungary. 
Table 1. Average habitat characteristics of the $150 \mathrm{~m}$ long sample reaches (sites) in the Hajagos stream. Each mean value is based on the pooled mean data of sampling units (see methods for details).

\begin{tabular}{lrrrrrc}
\hline & \multicolumn{2}{c}{ Summer } & \multicolumn{2}{c}{ Autumn } & \multicolumn{2}{c}{ Spring } \\
\cline { 2 - 7 } & Site 1 & Site 2 & Site 1 & Site 2 & Site 1 & Site 2 \\
\hline Width (m) & 5.9 & 3.2 & 3.6 & 3.6 & 4.9 & 4.7 \\
Sampled area (m $\left.{ }^{2}\right)$ & 885 & 480 & 540 & 540 & 735 & 705 \\
Depth (cm) & 78.1 & 23.9 & 50.1 & 27.2 & 73.3 & 50.0 \\
Velocity (cm s ${ }^{-1}$ ) & 5.1 & 5.2 & 5.1 & 5.1 & 19.3 & 20.7 \\
Silty sand (\%) & 31.7 & 20.0 & 50.0 & 10.7 & 13.0 & 3.3 \\
Sand (\%) & 1.7 & 1.7 & - & 7.7 & - & - \\
Fine gravel (\%) & 40.0 & 6.7 & 16.7 & 25.0 & 61.3 & 33.3 \\
Coarse gravel (\%) & 10.0 & 71.7 & 18.3 & 56.7 & 22.3 & 63.3 \\
Stone (\%) & 16.7 & - & 8.3 & - & 3.3 & - \\
Rock (\%) & - & - & 6.7 & - & - & - \\
Emergent plant (\%) & 63.3 & 60.0 & 92.3 & 78.3 & 31.7 & 51.7 \\
Submerged plant (\%) & 6.7 & - & 5.0 & 4.0 & 16.7 & 16.7 \\
Floating leaved plant (\%) & 11.7 & 1.7 & 2.7 & 0.2 & - & - \\
Filamentous algae (\%) & - & 16.7 & - & - & - & - \\
\hline
\end{tabular}

four transects were placed at each unit perpendicular to the main axis of the stream. We measured wet width of the channel with a tape measure, depth and current velocity with a meter stick and a water velocity meter (FP101 Global Flow Probe, Global Water Instrumentation Inc., Gold River, CA, USA), respectively, at five equally spaced points along each transect. At every transect point the occurrence and type of aquatic vegetation and substrate were recorded.

\section{Data analysis}

We used three-way factorial analysis of variance (ANOVA) in a nested design with three replicates (units) to test for differences in species richness or number of individuals between seasons, between sites within seasons, and between diel periods within sites and seasons. Species richness values were also compared using individual based rarefaction analyses to control for the likelihood of collecting more species when more individuals were collected (SimberLoff 1972). Individual based rarefaction curves were constructed separately for each season and day and night samples and by pooling data from the individual sampling units at each site (Fig. 4.) We used principal coordinate analysis (PCoA) to reveal patterns in species composition and abundance between sites, seasons and diel periods. The Jaccard and Bray-Curtis indices were used for comparing samples based on species composition and abundance data, respectively. Finally, nested permutational analysis of variance (PERMANOVA) was used to assess the differences in species composition and abundance data between seasons, between sites within seasons and between diel periods 
within sites and seasons. PERMANOVA uses analysis of variance using distance matrices and a permutation test with pseudo F-ratio to test difference in the multivariate data groups. Similarly to the PCoA, Jaccard and Bray-Curtis dissimilarity indices were used for species composition and abundance, respectively (LEGENDRE \& LEGENDRE 1998). Abundance data were standardized for unit area before all of the analyses. All statistical analyses were performed in the $R$ statistical environment (R CoRe TEAm 2013). PERMANOVA was conducted with 'adonis' function of the $\mathrm{R}$ package named vegan (ОкSANEN et al. 2013).

Table 2. Fish species, species codes (SC), total number of individuals and species density values (in parentheses, averaged over seasons) collected at Site 1 and Site 2 in the Hajagos stream during day and night sampling.

\begin{tabular}{|c|c|c|c|c|c|}
\hline \multirow[t]{2}{*}{ Species } & \multirow{2}{*}{$\begin{array}{l}\text { Species } \\
\text { code }\end{array}$} & \multicolumn{2}{|c|}{ Site 1} & \multicolumn{2}{|c|}{ Site 2} \\
\hline & & Day & Night & Day & Night \\
\hline Abramis brama (L.) & abrbra & $1(<0.001)$ & $2(<0.001)$ & - & - \\
\hline Alburnus alburnus (L.) & albalb & $67(0.030)$ & $40(0.016)$ & $3(0.002)$ & $12(0.008)$ \\
\hline Ameiurus melas (Rafinesque) & amemel & $7(0.003)$ & $9(0.005)$ & - & $3(0.002)$ \\
\hline Ballerus ballerus (L.) & balbal & $4(0.002)$ & - & - & - \\
\hline Barbatula barbatula (L.) & ortbar & - & $2(0.001)$ & $15(0.011)$ & $9(0.006)$ \\
\hline Blicca bjoerkna (L.) & blibjo & $12(0.005)$ & $147(0.065)$ & - & - \\
\hline Carassius gibelio (Bloch) & cargib & $4(0.002)$ & $10(0.005)$ & $9(0.006)$ & $18(0.012)$ \\
\hline $\begin{array}{l}\text { Cobitis elongatoides (Bacescu et } \\
\text { Maier) }\end{array}$ & cobelo & $12(0.006)$ & $9(0.004)$ & $4(0.002)$ & $9(0.005)$ \\
\hline Esox lucius (L.) & esoluc & $65(0.031)$ & $57(0.026)$ & $31(0.019)$ & $60(0.038)$ \\
\hline Gobio sp. (L.) & gobgob & $1(<0.001)$ & - & $13(0.009)$ & $17(0.011)$ \\
\hline Lepomis gibbosus (L.) & lepgib & $4(0.002)$ & $6(0.003)$ & - & $2(0.001)$ \\
\hline Leucaspius delineatus (Heckel) & leudel & $2(0.001)$ & $1(<0.001)$ & - & - \\
\hline Leucaspius idus (L.) & leuidu & $4(0.002)$ & $26(0.012)$ & - & - \\
\hline Leuciscus leuciscus (L.) & leuleu & $12(0.006)$ & $19(0.007)$ & $8(0.005)$ & $38(0.024)$ \\
\hline Misgurnus fossilis (L.) & misfos & - & $4(0.002)$ & $1(<0.001)$ & $3(0.002)$ \\
\hline Neogobius fluviatilis (Pallas) & neoflu & $19(0.009)$ & $13(0.005)$ & - & - \\
\hline Neogobius melanostomus (Pallas) & neomel & $35(0.017)$ & $19(0.009)$ & $3(0.002)$ & $11(0.008)$ \\
\hline Perca fluviatilis (L.) & perflu & $5(0.002)$ & $6(0.003)$ & $10(0.005)$ & $11(0.007)$ \\
\hline Phoxinus phoxinus (L.) & phopho & $1(<0.001)$ & $1(<0.001)$ & - & - \\
\hline Proterorhinus semilunaris (Pallas) & prosem & $99(0.052)$ & $64(0.034)$ & $1(<0.001)$ & $13(0.008)$ \\
\hline $\begin{array}{l}\text { Pseudorasbora parva (Temminck } \\
\text { et Schlegel) }\end{array}$ & psepar & $67(0.030)$ & $63(0.028)$ & $43(0.020)$ & $57(0.027)$ \\
\hline Rhodeus sericeus (Pallas) & rhoser & $456(0.222)$ & $558(0.286)$ & $74(0.049)$ & $35(0.024)$ \\
\hline Rutilus rutilus (L.) & rutrut & $182(0.079)$ & $86(0.040)$ & $31(0.021)$ & $69(0.045)$ \\
\hline Scardinius erythrophthalmus (L.) & scaery & $42(0.019)$ & $17(0.008)$ & $6(0.004)$ & $13(0.009)$ \\
\hline Squalius cephalus (L.) & squcep & $72(0.033)$ & $56(0.027)$ & $53(0.032)$ & $147(0.094)$ \\
\hline Tinca tinca (L.) & tintin & $4(0.002)$ & $1(<0.001)$ & - & - \\
\hline
\end{tabular}




\section{RESULTS}

A total of 3,225 specimens representing 26 species were collected during the study (Table 2). Basic data about number of species and their composition and abundance reflected more the effect of spatial position of the sampling site than the effect of season (although season effect was also significant) or diel period (Fig. 2). Both mean species richness (i.e. averaged over $50 \mathrm{~m}$ sampling units) and mean number of individuals collected were significantly higher at
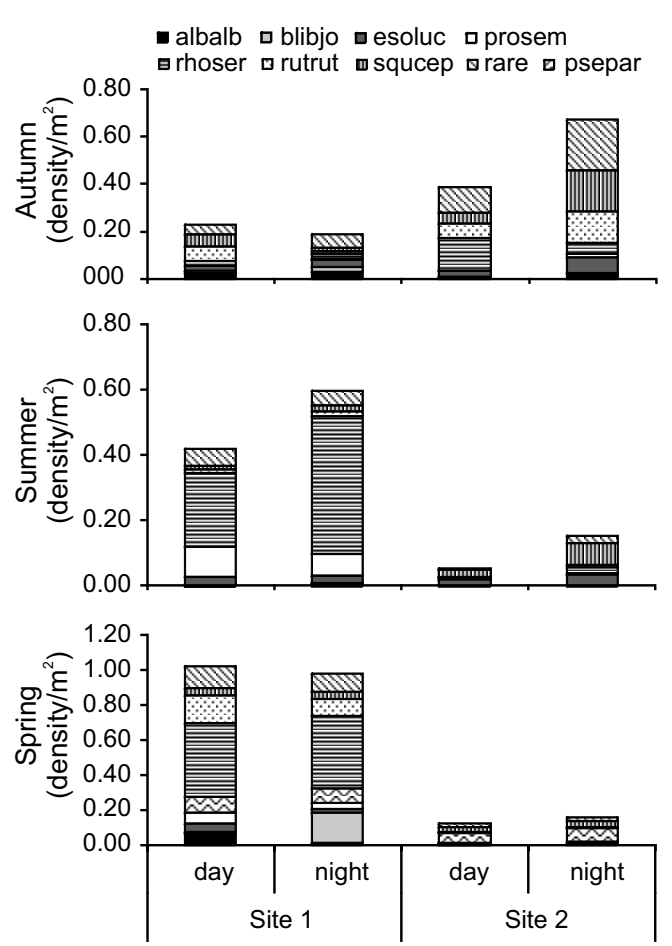

Fig. 2. Fish assemblage composition (standardized for unit area, averaged over $50 \mathrm{~m}$ sampling units) at Site 1 and Site 2 during day and night time samplings in summer and autumn 2013 and spring 2014. Rare species (species without the 8 most abundant ones) were treated together. Species abbreviations are as follows. albalb - bleak; blibjo - white bream; esoluc - pike; prosem - tubenose goby; psepar - topmouth gudgeon; rhoser - bitterling; rutrut - roach; squcep - chub; rare - rare (i.e. non dominant) species.
Site 1 (at the mouth) than at Site 2 (6 km upstream) (Fig. 3, Table 3). However, neither of them differed significantly between day and night samples (Fig. 3, Table 3). Individual based rarefaction curves confirmed the results obtained on species richness at the sampling unit level (Fig. 4). Especially, they confirmed the lack of significant differences between day and night samples in species richness (except in the case of summer for Site 2 where there was a clear difference between day and night patterns). However, they also revealed the strong effect of season on the results on site level species richness. They indicated high differences in species richness between the two study sites in spring, but less clear differences in summer and autumn.

For species composition data the PCoA ordination of Jaccard dissimilarity matrix showed a clear separation of sites along the first axis (Fig. 5a). This separation was generally related to the presence of those species at Site 1 that were not caught at Site 2 (e.g. white bream Blicca bjoerkna) (Fig. $5 c$, Table 2). Some of these species prefer larger water bodies (e.g. ide 
Table 3. Summary results of the nested three-way factorial analysis of variance (ANOVA) for species richness and number of individuals (standardized for unit area).

\begin{tabular}{lrrrr}
\hline Species richness & d.f. & MS & \multicolumn{1}{c}{$F$} & \multicolumn{1}{c}{$P$} \\
\hline Season & 2 & $<0.001$ & 1.55 & 0.234 \\
Season : Site & 3 & 0.002 & 12.17 & $<0.001$ \\
Season : Site : Time of day & 6 & $<0.001$ & 0.54 & 0.774 \\
Residuals & 24 & $<0.001$ & & \\
\hline Number of individuals & d.f. & MS & $F$ & $P$ \\
\hline Season & 2 & 0.23 & 1.59 & 0.225 \\
Season : site & 3 & 1.01 & 6.92 & 0.002 \\
Season : Site : Time of day & 6 & 0.03 & 0.23 & 0.965 \\
Residuals & 24 & 0.15 & & \\
\hline
\end{tabular}

(Leuciscus idus), blue bream (Ballerus ballerus)) and may use tributary mouth periodically. Overall, between site and seasonal differences in species composition were much higher than between day and night samples. The PCoA plot of Bray-Curtis dissimilarity matrix for abundance data also represented differences between Site 1 and Site 2 along the first axis, but no clear differences between day and night samples (Fig. 5b). Examples of fishes associated with Site 1 were bitterling (Rhodeus sericeus), black bullhead (Ameiurus melas) and tubenose goby (Proterorhinus semilunaris), while fishes associated with Site 2 were chub (Squalius cephalus), and perch (Perca fluviatilis) (Fig. 5d).

PERMANOVA analyses confirmed the results of exploratory analyses and showed that species composition and abundance of fish differed significantly between seasons and sites, but not between diel periods (Table 4).
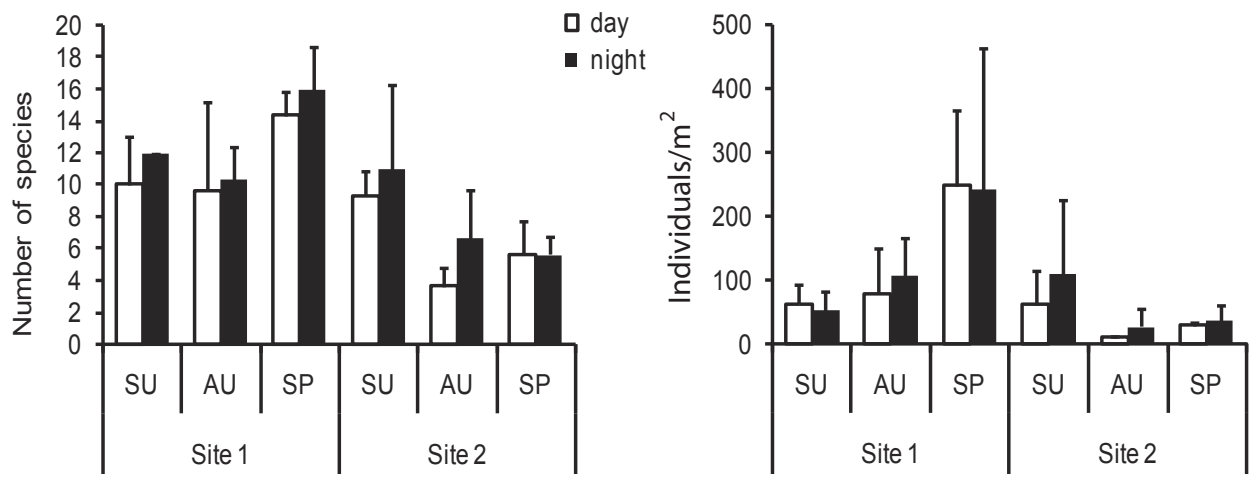

Fig. 3. Mean species richness (averaged over $50 \mathrm{~m}$ sampling units, \pm S.D.) (a) and number of individuals collected (standardized for unit area) (b) at Site 1 and Site 2 during day and night time samplings. Season abbreviations are as follows. SU - summer; AU - autumn; $\mathrm{SP}$ - spring. 
Table 4. Summary results of the nested permutational analysis of variance (PERMANOVA) for species composition and abundance data (standardized for unit area).

\begin{tabular}{lrcccr}
\hline Species composition & d.f. & MS & $F$ & $\mathrm{R}^{2}$ & $P$ \\
\hline Season & 2 & 0.79 & 5.97 & 0.21 & $<0.001$ \\
Season : site & 3 & 0.69 & 5.23 & 0.27 & $<0.001$ \\
Season : Site : Time of day & 6 & 0.12 & 0.93 & 0.10 & 0.620 \\
Residuals & 24 & 0.13 & & 0.42 & \\
Total & 35 & & & 1.00 & \\
\hline Abundance & d.f. & MS & $F$ & $\mathrm{R}^{2}$ & $P$ \\
\hline Season & 2 & 0.92 & 5.69 & 0.19 & $<0.001$ \\
Season : site & 3 & 1.05 & 6.49 & 0.32 & $<0.001$ \\
Season : Site : Time of day & 6 & 0.16 & 0.96 & 0.10 & 0.529 \\
Residuals & 24 & 0.16 & & 0.40 & \\
Total & 35 & & & 1.00 & \\
\hline
\end{tabular}
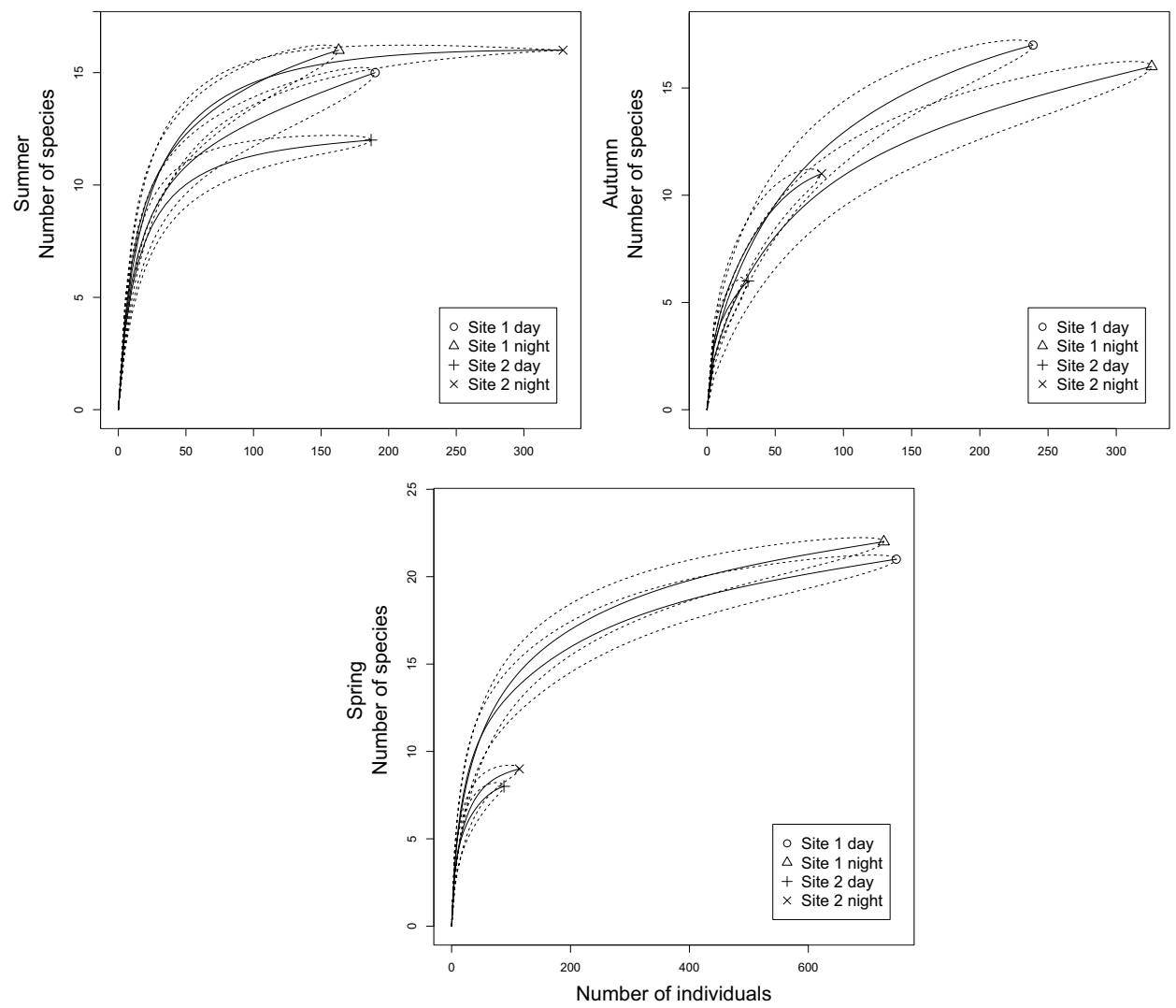

Fig. 4. Individual based rarefaction curves for summer, autumn and spring. 


\section{DISCUSSION}

Contrary to our hypothesis, we found no significant effect of diel period on the assemblage level attributes of stream fish assemblages at any spatial position of the sampling sites. We can conclude therefore, that neither sampling effectiveness nor fish migration and/or differential habitat use influenced significantly the differences in fish assemblage structure between day and night, when compared with the effect of seasonal and spatial (between site) changes.

Spatial position of the sampling site had the most influential effect on fish assemblage attributes compared with seasonal and/or day night patterns.
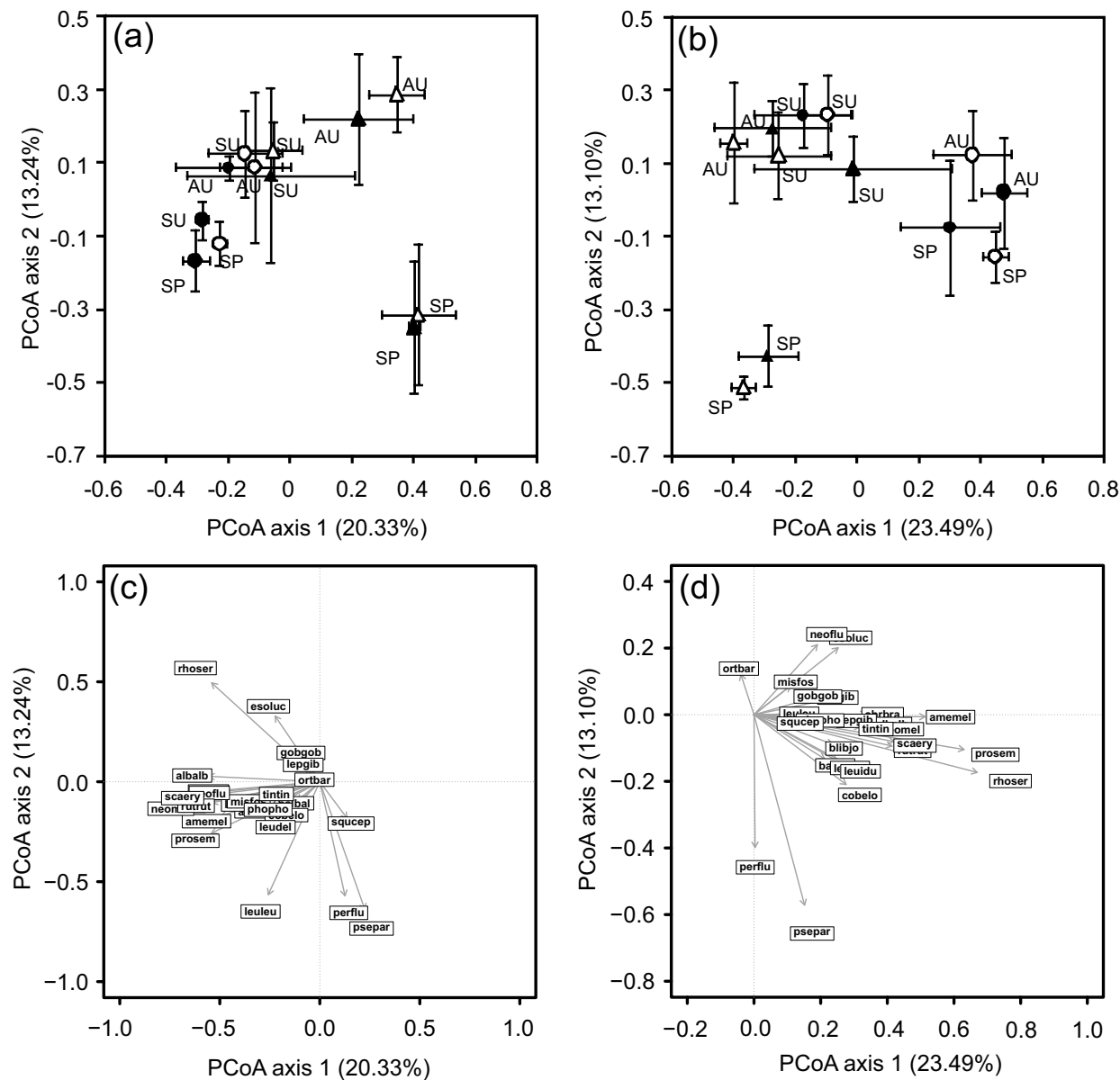

Fig. 5. Principal Coordinate Analysis (PCoA) summarizing the variation across sites (averaged over $50 \mathrm{~m}$ sampling units, \pm S.D.) and diel periods for (a) species composition and (b) abundance data (standardized for unit area) and their associated species loaded (c and d). $O$ - Site 1-day; - - Site 1-night; $\triangle$ - Site 2-day; $\boldsymbol{\Delta}$ - Site 2-night. Season abbreviations are as follows. SU - summer; AU - autumn; SP - spring. For species code abbreviations see Table 2. 
It is well known, that stream fish assemblages are influenced by the position of the site along the upstream-downstream gradient (Osborne \& WiLEY 1992, Schlosser \& Angermeier 1995, Thornbrugh \& Gido 2009, Czeglédi et al. 2015). Increasing complexity and size of the habitat downstream, differential rates of immigration and extinction are some of the most possible factors responsible for this typical longitudinal pattern (SChlosser 1982, Power et al. 1988, Miyazono \& TAYLOR 2013). We found significantly higher species richness and collected more individuals (on average) at Site 1 than at Site 2 suggesting preferential habitat use and maybe higher immigration and lower emigration rates at Site 1. Dissimilarity of species composition and abundances were also significant between the two sites. This is in accordance with the presence and higher abundance of mainstem fishes at Site 1 (e.g. bleak Alburnus alburnus, white bream, tubenose goby) and more upstream species at Site 2 (e.g. spined loach Cobitis elongatoides, stone loach Barbatula barbatula, chub, gudgeon Gobio sp.). It seems that mainstem fishes use only the most downstream reaches of the Hajagos. There may be two possible explanations for this pattern. First, reduced habitat size in an upstream direction (shallower water depth and narrower width) limits the movement possibility and represent unsuitable habitat for mainstream fishes (Schlosser 1982, Matthews 1998). Second, in the vegetation period (i.e. from late spring to autumn), heavy macrovegetation coverage may restrict upstream movement of large bodied fish (ERós \& Grant 2015).

Seasonal differences in fish assemblage structure were also significant at both sites. Of these, the most contrasting were the changes in species composition and abundance per unit area over seasons. Spawning migration and more increased activity of fish in spring can be the two most important factors for shaping these patterns. Species which did not appear in summer and autumn samples but were detected in the spring sample both at day and night were for example blue bream and stone moroko (Pseudorasbora parva). However, most of the dominant tributary species (e.g. bitterling, stone moroko, roach Rutilus rutilus) are common in both the Hajagos and the mainstem Marcal, so we cannot really disentangle the effect of mainstem-tributary migration on seasonal changes.

Although day and night changes were relatively minor for all assemblage attributes (species richness, composition and abundance of fish), the basic data (Fig. 2) suggested some differences between day and night samples in all seasons and at both sites. Contrary to many studies which use only single pass electrofishing, we used three pass removals to maximize sample representativity. Therefore, we believe the data suggest more the rate of movement of the different species in and out of the sampling site, rather than differences in sampling effectiveness between day and night (see Appendix 1). The most noteworthy difference was the 25 times increase in the abundance of white bream by night at the mouth (Site 1) in spring. This may suggest the spawning migration of white 
bream at night in this period of the year and/or the use of the tributary mouth for habitat (i.e. feeding, refuging). In fact white bream has been shown to move to the littoral zone of rivers by night (Wolter \& FreyHof 2004, Erős et al. 2008).

Although our knowledge about diel activity and diel habitat use in fish other than salmonids is limited in small streams, it seems that looking for hiding and feeding place are two factors that may influence diel changes in fish distribution (Heggenes et al. 1999, Lewin et al. 2004, Copp et al. 2005, 2008). One of the most general factors responsible for the movement between the relatively safe tributary mouth and more hazardous river is a trade-off between predator avoidance and resource use (COPp \& JuRAJDA 1993, BECKER et al. 2011). One possible reason for the lack of significant effect of diel period in this system could be that mainstem fish find similarly suitable area for resting and hiding in the near shore habitat, which is also densely vegetated. Aquatic vegetation also provides food resources for algivorous and invertivorous fishes (WERNER et al. 1983).

In conclusion, our study suggests that fish assemblages in tributaries are more influenced by the spatial position of the sampling site than by the diel period, which had rather negligible effects in the Hajagos. The study also suggests that daytime electrofishing is highly effective for the accurate assessment of stream fish assemblages in this stream and could be a reliable method for any model of community organization (e.g. food web studies).

Acknowledgements - We would like to express of our thanks for the numerous people who helped in the field work including András Specziár, Árpád Ferincz, Gergely Erős, András Erős. We also thank László Antal for his help in editing Figure 1. This work was supported by the OTKA K104279 grant and the Bolyai János Research Scholarship of the Hungarian Academy of Sciences (Tibor Erős). The work of István Czeglédi was supported by the European Union and the State of Hungary, co-financed by the European Social Fund in the framework of TÁMOP 4.2.4. A/2-11-1-2012-0001 'National Excellence Program'.

\section{REFERENCES}

Anderson, J. F., Main, A. J., Ferrandino, F. J. \& Andreadis, T. G. (2007) Nocturnal activity of mosquitoes (Diptera: Culicidae) in a West Nile virus focus in Connecticut. Journal of Medical Entomology 44: 1102-1108. http://dx.doi.org/10.1093/jmedent/44.6.1102

Arrington, D.A. \& Winemiller, K.O. (2003) Diel changeover in sandbank fish assemblages in a Neotropical floodplain river. Journal of Fish Biology 63: 442-459. http://dx.doi. org/10.1046/j.1095-8649.2003.00167.x

Baumann, P. C. \& Kitchell, J. F. (1974) Diel patterns of distribution and feeding of bluegill (Lepomis macrochirus) in Lake Wingra, Wisconsin. Transactions of the American Fisheries Society 103: 255-260. http://dx.doi.org/10.1577/1548-8659(1974)103<255:DPO $\mathrm{DAF}>2.0 . \mathrm{CO} ; 2$ 
Baumgartner, L. J., Stuart, I. G. \& Zampatti, B. P. (2008) Determining diel variation in fish assemblages downstream of three weirs in a regulated lowland river. Journal of Fish Biology 72: 218-232. http://dx.doi.org/10.1111/j.1095-8649.2007.01696.x

Becker, A., Cowley, P. D., Whitfield, A. K., Järnegren, J. \& NÆsje, T. F. (2011) Diel fish movements in the littoral zone of a temporarily closed South African estuary. Journal of Experimental Marine Biology and Ecology 406: 63-70. http://dx.doi.org/10.1016/j. jembe.2011.06.014

Cao, Y., Hawkins, C. P. \& Vinson, M. R. (2003) Measuring and controlling data quality in ecological assemblage surveys with a special reference to stream benthic macroinvertebrates. Freshwater Biology 48: 1898-1911. http://dx.doi.org/10.1046/j.13652427.2003.01123.x

Copp, G.H. (2008) Putting multi-dimensionality back into niche breadth: diel vs. day-only niche separation in stream fishes. Fundamental and Applied Limnology 170: 273-280. http://dx.doi.org/10.1127/1863-9135/2008/0170-0273

Copp, G. H. (2010) Patterns of diel activity and species richness in young and small fishes of European streams: a review of 20 years of point abundance sampling by electric fishing. Fish and Fisheries 11: 439-460. http://dx.doi.org/10.1111/j.1467-2979.2010.00370.x

Copp, G. H. \& Jurajda, P. (1993) Do small riverine fish move inshore at night? Journal of Fish Biology 43: 229-241. http://dx.doi.org/10.1111/j.1095-8649.1993.tb01190.x

Copp, G. H., Spathari, S. \& Turmel, M. (2005) Consistency of diel behaviour and interactions of stream fishes and invertebrates during summer. River Research and Applications 21: 75-90. http://dx.doi.org/10.1002/rra.833

Craig, J. F. (1977) Seasonal changes in the day and night activity of adult perch, Perca fluviatilis L. Journal of Fish Biology 11: 161-166. http://dx.doi.org/10.1111/j.1095-8649.1977.tb04109.x

CunJAK, R. A. (1988) Behaviour and microhabitat of young Atlantic salmon (Salmo salar) during winter. Canadian Journal of Fisheries and Aquatic Sciences 45: 2156-2160. http:// dx.doi.org/10.1139/f88-250

Cunjak, R. A., Prowse, T. D. \& Parrish, D. L. (1998) Atlantic salmon (Salmo salar) in winter: "the season of parr discontent"? Canadian Journal of Fisheries and Aquatic Sciences 55: 161-180. http://dx.doi.org/10.1139/d98-008

Czeglédi, I., SÁly, P., TakÁcs, P., Dolezsai, A., Nagy S. A. \& Erôs, T. (2015) The scales of variability of stream fish assemblages at tributary confluences. Aquatic Sciences http:// dx.doi.org/1007/s00027-015-0454-z

David, B. O. \& Closs, G. P. (2003) Seasonal variation in diel activity and microhabitat use of an endemic New Zealand stream-dwelling galaxiid fish. Freshwater Biology 48: 1765-1781. http://dx.doi.org/10.1046/j.1365-2427.2003.01127.x

Erős, T., Tóth, B., Sevcsik, A. \& Schmera, D. (2008) Comparison of fish assemblage diversity in natural and artificial rip-rap habitats in the littoral zone of a large river (River Danube, Hungary). International Review of Hydrobiology 93: 88-105. http://dx.doi. org/10.1002/iroh.200710976

ERôs, T. \& Schmera, D. (2010) Spatio-temporal scaling of biodiversity and the speciestime relationship in a stream fish assemblage. Freshwater Biology 55: 2391-2400. http:// dx.doi.org/10.1111/j.1365-2427.2010.02438.x

Erós, T. \& Grant, E. H. C. (2015) Unifying research on the fragmentation of terrestrial and aquatic habitats: patches, connectivity and the matrix in riverscapes. Freshwater Biology 60: 1487-1501. http://dx.doi.org/10.1111/fwb.12596

Grossman, G. D. \& RatajczaK, R. E. (1998) Long-term patterns of microhabitat use by fish in a southern Appalachian stream from 1983 to 1992: effects of hydrologic pe- 
riod, season, and fish length. Ecology of Freshwater Fish 7: 108-131. http://dx.doi. org/10.1111/j.1600-0633.1998.tb00178.x

Harka, Á., Szepesi, Zs. \& NAGY, L. (2009) A Marcal halállományának faunisztikai felmérése. Pisces Hungarici 3: 27-32. [in Hungarian with English summary]

Heggenes, J., Krog, O. M. W., Lindas, O. R., Dokк, J. G. \& Bremnes, T. (1993) Homeostatic behavioural responses in a changing environment: brown trout (Salmo trutta) become nocturnal during winter. Journal of Animal Ecology 62: 295-308. http://dx.doi. org $/ 10.2307 / 5361$

Heggenes, J., Bagliniere, J. L. \& Cunjak, R. A. (1999) Spatial niche variability for young Atlantic salmon (Salmo salar) and brown trout, (S. trutta) in heterogeneous streams. Ecology of Freshwater Fish 8: 1-21. http://dx.doi.org/10.1111/j.1600-0633.1999.tb00048.x

Helfman, G. S. (1993) Fish behaviour by day, night, and twilight. Pp. 479-512. In: РітснER, T. J. (ed.): Behaviour of Teleost Fishes. 2nd ed. Chapman and Hall, London. http:// dx.doi.org/10.1007/978-94-011-1578-0_14

Hiscock, M. J., Scruton, D. A., Brown, J. A. \& Clarke, K. D. (2002) Winter movement of radio-tagged juvenile Atlantic salmon in Northeast Brook, Newfoundland. Transactions of the American Fisheries Society 131: 577-581. http://dx.doi.org/10.1577/15488659(2002)131<0577:WMORTJ>2.0.CO;2

Kennard, M. J. Pusey, B. J. Harch, B. D., Dore, E. \& Arthington, A. H. (2006) Estimating local stream fish assemblage attributes: sampling effort and efficiency at two spatial scales. Marine and Freshwater Research 57: 635-653. http://dx.doi.org/10.1071/MF06062

Lapointe, N. W. R., Corkum, L. D. \& MandraK, N. E. (2006) A comparison of methods for sampling fish diversity in shallow offshore waters of large rivers. North American Journal of Fisheries Management 26: 503-513. http://dx.doi.org/10.1577/M05-091.1

Legendre, P. \& Legendre, L. (1998) Numerical ecology. 2nd ed. Elsevier Science BV, Amsterdam.

Lewin, W-C., Окиn, N. \& Menner, T. (2004) Determinants of the distribution of juvenile fish in the littoral area of a shallow lake. Freshwater Biology 49: 410-424. http://dx.doi. org/10.1111/j.1365-2427.2004.01193.x

Maher, W. A., Cullen, P. W. \& Norris, R. H. (1994) Framework for designing sampling programs. Environmental Monitoring and Assessment 30: 139-162. http://dx.doi. org/10.1007/BF00545619

Matthews, W. J. (1998) Patterns in freshwater fish ecology. Chapman and Hall, New York. http://dx.doi.org/10.1007/978-1-4615-4066-3

Meador, M. R., McIntyre, J. P. \& Pollock, K. H. (2003) Assessing the efficacy of singlepass backpack electrofishing to characterize fish community structure. Transactions of the American Fisheries Society 132: 39-46. http://dx.doi.org/10.1577/15488659(2003)132<0039:ATEOSP >2.0.CO;2

Murphy, B. R. \& Willis, D. W. (1996) Fisheries techniques. 2nd ed. American Fisheries Society, Bethesda, Maryland.

Miyazono, S. \& TAylor, C. M. (2013) Effects of habitat size and isolation on species immigration-extinction dynamics and community nestedness in a desert river system. Freshwater Biology 58: 1303-1312. http://dx.doi.org/10.1111/fwb.12127

NieLSEN, E. T. (1984) Relation of behavioural activity rhythms to the changes of day and night. A revision of views. Behaviour 89: 147-173. http://dx.doi.org/10.1163/156853984X00083

Oksanen, J., Blanchet, F. B., Kindt, R., Legendre, P., Minchin, P. R., O’Hara, R. B., Simpson, G. L., Solymos, P., Stevens, M. H. H. \& Wagner, H. (2013) vegan: Community Ecology Package. R package version 2.0-10. http://CRAN.R-project.org/package=vegan 
Osborne, L. L. \& Wiley, M. J. (1992) Influence of tributary spatial position on the structure of warmwater fish communities. Canadian Journal of Fisheries and Aquatic Sciences 49: 671-481. http://dx.doi.org/10.1139/f92-076

Pierce, C. L., Corcoran, A. M., Gronbach, A. N., Hsia, S., Mullarkey, B. J. \& Schwartzhoff, A. J. (2001) Influence of diel period on electrofishing and beach seining assessments of littoral fish assemblages. North American Journal of Fisheries Management 21: 918926. http://dx.doi.org/10.1577/1548-8675(2001)021<0918:IODPOE>2.0.CO;2

Power, M. E., Stout, R. J., Cushing, C. E., Harper, P. P., Hauer, F. R., Matthews, W. J., Moyle, P. B., Statzner, B. \& Wais de Badgen, I. R. (1988) Biotic and abiotic controls in river and stream communities. Journal of Northern American Benthological Society 7: 456-479. http://dx.doi.org/10.2307/1467301

R Core Team (2013) R: A language and environment for statistical computing. R Foundation for Statistical Computing, Vienna, Austria. ISBN 3-900051-07-0. http://www.R409project.org

Railsback, S. F., Harvey, B. C., Hayse, J. W. \& LaGory, K. E. (2005) Tests of theory for diel variation in salmonid feeding activity and habitat use. Ecology 86: 947-959. http:// dx.doi.org/10.1890/04-1178

Reebs, S. G. (2002) Plasticity of diel and circadian activity rhythms in fishes. Reviews in Fish Biology and Fisheries 12: 349-371. http://dx.doi.org/10.1023/A:1025371804611

Riha, M., Ricard, D., Vasek, M., Prchalová, M., Mrkvicka, T., Juza, T., Cech, M., Drastik, V., Muska, M., Kratochvil, M., Peterka, J., Tuser, M., Sed’a, J., Blabolil, P., Bláha, M., Wanzenböck, J. \& Kubecka, J. (2015) Patterns in diel habitat use of fish covering the littoral and pelagic zones in a reservoir. Hydrobiologia 747: 111-131. http://dx.doi. org/10.1007/s10750-014-2124-x

Roberts, J. H. \& Hitt, N. P. (2010) Longitudinal structure in temperate stream fish communities: evaluating conceptual models with temporal data. American Fisheries Society Symposium 73: 281-299.

Salas, A. K. \& SNyder, E. B. (2010) Diel fish habitat selection in a tributary stream. American Midland Naturalist 163: 33-43. http://dx.doi.org/10.1674/0003-0031-163.1.33

SANDERS, R. E. (1992) Day versus night electrofishing catches from near-shore waters of the Ohio and Muskingum Rivers. Ohio Journal of Science 92: 51-59.

Schlosser, I. J. (1982) Fish community structure and function along two habitat gradients in a headwater stream. Ecological Monographs 52: 395-414. http://dx.doi. org $/ 10.2307 / 2937352$

Schlosser, I. J. (1991) Stream fish ecology: A landscape perspective. Bioscience 41: 704-712. http://dx.doi.org/10.2307/1311765

Schlosser, I. J. \& Angermeier, P. L. (1995) Spatial variation in demographic processes of lotic fishes: conceptual models, empirical evidence, and implications for conservation. American Fisheries Society Symposium 17: 392-401.

Simberloff, D. S. (1972) Properties of the rarefaction diversity measurement. American Naturalist 106: 414-418. http://dx.doi.org/10.1086/282781

Specziár, A., TAKács, T., Czeglédi, I. \& Erôs, T. (2012) The role of the electrofishing equipment type and the operator in assessing fish assemblages in a non-wadeable lowland river. Fisheries Research 125-126: 99-107. http://dx.doi.org/10.1016/j.fishres.2012.02.014

Thornbrugh, D. J. \& Gido, K. B. (2010) Influence of spatial positioning within stream networks on fish assemblage structure in the Kansas River basin, USA. Canadian Journal of Fisheries and Aquatic Sciences 67: 143-156. http://dx.doi.org/10.1139/F09-169

Werner, E. E., Mittelbach, G. G., Hall, D. J. \& Gilliam, J. F. (1983) Experimental tests of optimal habitat use in fish - the role of relative habitat profitability. Ecology 64: 1525-1539. http://dx.doi.org/10.2307/1937507 
Wolter, C. \& Freyhof, J. (2004) Diel distribution patterns of fishes in a temperate large lowland river. Journal of Fish Biology 64: 632-642. http://dx.doi.org/10.1111/j.10958649.2004.00327.x

Received August 5, 2015, accepted December 21, 2015, published May 6, 2016

Appendix 1. Cumulative catches of fish removals at Site 1 and Site 2 during day and night in summer and autumn 2013 and spring 2014. Species abbreviations are as follows: albalb - bleak; blibjo - white bream; esoluc - pike; prosem - tubenose goby; psepar - topmouth gudgeon; rhoser - bitterling; rutrut - roach; squcep - chub; rare - rare (i.e. non dominant) species. Note that the diagram of spring samples has a different scale on the y axis.
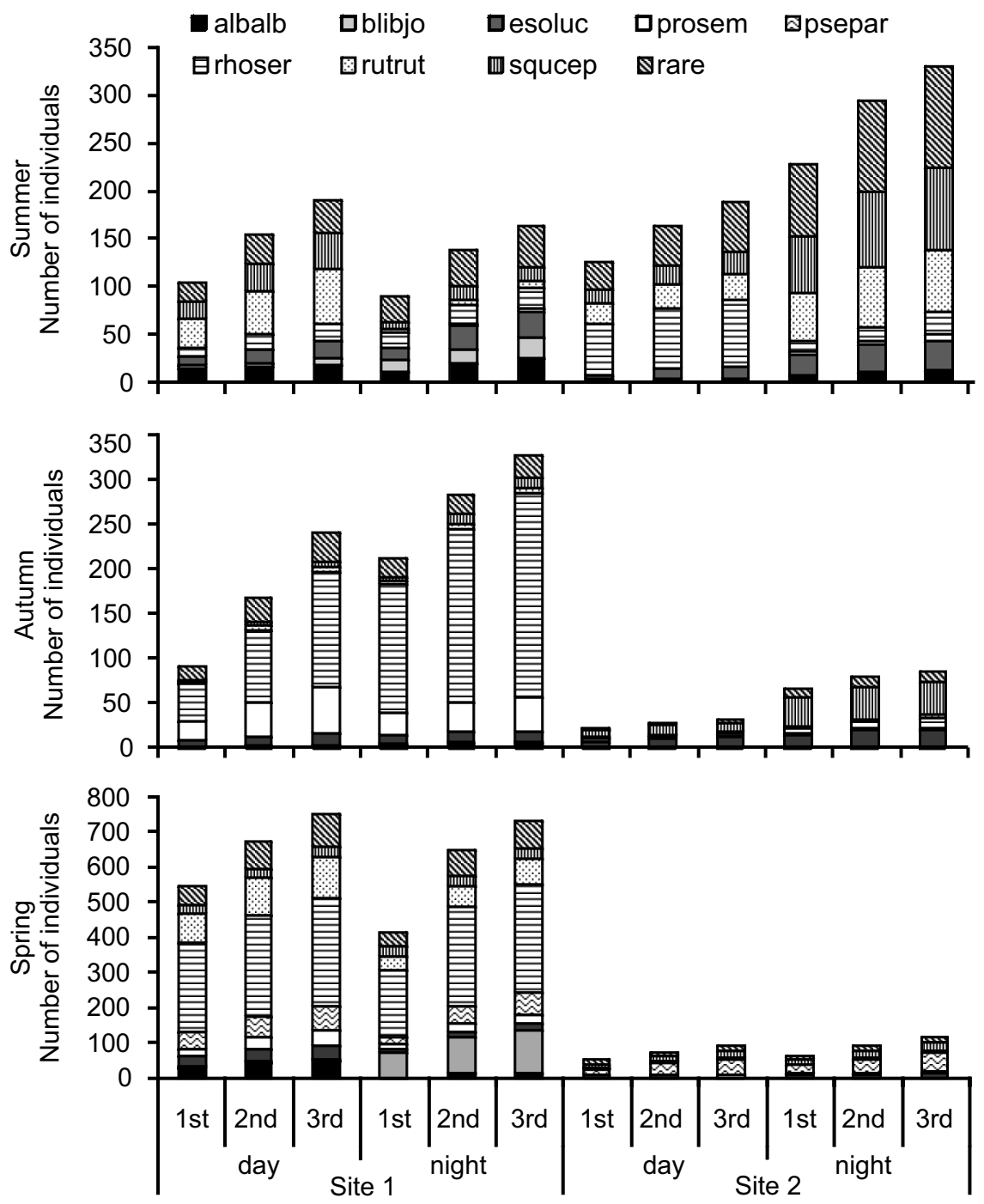